\title{
时空压缩下的中国乡村空间生产 一广州市域乡村投资为例
}

\author{
周尚意, 许伟麟 \\ (北京师范大学地理科学学部, 北京 100875)
}

\begin{abstract}
摘 要: 党的十九大报告提出 “乡村振兴”战略, 人文地理学者的角色是从空间和区域的角度参与各类乡村振兴实践 和思考。马克思主义地理学代表人物大卫·哈维指出, “时空压缩”现象加剧了资本积累的危机, 要消除危机, 必须 从生产方式和生产关系的革命人手。本文以 2015-2017年广州市企业投资中的乡村项目为例, 分析哪些项目是消 除区域发展两级分化、抵制资本纯粹追逐利润的, 从而为政府重点鼓励何类项目提供依据。本文采用经验主义的 数据统计分析方法, 主要研究结论为: (1)从空间分布上看, 2015-2017年企业投资在广州乡村的项目大部分是按照 “纯粹”市场原则分布的, 即投资项目以近郊为主, 高投资额的投资项目也集中在近郊, 这种分布是“时空压缩”的结 果。22015-2017年少部分投资在广州乡村的项目并非“纯粹”追求利润, 它们主要是为改变乡村生活的环境质量, 而非生产经营性的、“空间修复”型的项目,更能体现人们对幸福生活本质理解的积极性项目。
\end{abstract}

关键 词: 乡村振兴; 时空压缩; 投资空间分布;广州

\section{1 引言}

党的十九大报告中提出了乡村振兴战略, 将 “三农”问题作为国计民生的根本性问题。报告中 提出解决三农问题的目标为:产业兴旺、生态宜居、 乡风文明、治理有效、生活富裕。实现乡村振兴战 略目标的途径是: 建立健全城乡融合发展体制机制 和政策体系, 加快推进农业农村现代化。2018 年 1 月 2 日, 中共中央、国务院发布了《中共中央国务院 关于实施乡村振兴战略的意见》, 对乡村振兴战略 进行更加细致的部署。

地理学者参与乡村振兴的实践要通过自己的 学科视角介人。今年是马克思诞辰 200 周年, 也是 《共产党宣言》发表 170 周年。马克思主义地理学代 表人物哈维(2003)用资本运动和再生产理论分析了 当今世界经济不平衡发展的空间格局, 他提出的时 空压缩(time-space compression)是本文分析的基 础。党的十九大报告中指出, 中国社会主要矛盾已 经转化为人民日益增长的美好生活需要和不平衡 不充分的发展之间的矛盾。城乡发展的不平衡是 这一矛盾的突出体现。“时空压缩”理论打破了以往 的城乡定义, 将城乡之间的不平衡, 拓展为都市化 地带及周边地区与其他地区之间的不平衡。

哈维认为时空压缩可以带来两种危机,一是文 化表征领域的危机，二是资本积累领域的危机。按 照马克思主义的观点, 只有改变生产方式、生产关 系, 才能消除这两种危机。而改变的最终目的是统 筹人的经济生活、文化生活、政治生活, 从而最终走 向人的政治解放(崔丽华, 2011)。本文结合企业乡 村投资项目的数据, 只讨论资本积累危机, 而不讨 论文化表征危机,主要分析企业投资乡村是以哪种 形式抵抗资本积累的危机。许多学科的学者都讨

收稿日期: 2018-04-21; 修订日期:2018-05-06。

基金项目: 国家自然科学基金项目(41771148); 中国西南地缘环境与边疆发展协同创新中心项目; 国家社科基金重大项目 (14ZDB139) [Foundation: National Natural Science Foundation of China, No.41771148; Collaborative Innovation Center for Geopolitical Setting of Southwest China and Borderland Development; Major Research Plan of National Social Science Foundation of China, No.14ZDB139]。

作者简介: 周尚意(1960-), 女, 广西罗城人,教授,博士生导师,主要从事社会文化地理学研究, E-mail: twizsy@163.com。 Xu W L. 2018. A geographical analysis on the positive investment projects in rural vitalization under time-space compression: A case study of Guangzhou City[J]. Progress in Geography, 37(5): 647-654.]. DOI: 10.18306/dlkxjz.2018.05.008 
论时空压缩的现象, 例如经济学 (Mahoney et al, 2009)、社会学(Yu, 2016)、政治学(Smith M, 2011)、心 理学 (Sullivan et al, 2016), 甚至是文学 (Poklad, 2017)的研究成果。地理学者是从空间的角度分析 时空压缩影响的,例如从交通技术改变空间可达性 角度分析全球化中的时空压缩(Brunn et al, 1991; Warf, 2011); 从地缘政治的角度分析时空压缩下的 国家关系(Agnew, 2001)。本文从空间的角度, 分析 时空压缩背景下企业投资乡村的项目分布, 以及这 种分布反映的资本流, 及其背后的积极动机和消极 动机。

\section{2 时空压缩下的积累危机与反危机研究}

\section{1 时空压缩下的空间不平衡发展}

资本主义是造成空间不均衡发展的根本原 因。哈维的弟子 $\operatorname{Smith}(1990)$ 在《不均衡的发展》一 书中提出了 “地理跷跷板” (geographical seesaw)理 论, 用于解释由于资本趋利的空间选择造成的空间 不平衡。Smith 认为资本总是从平均利润率低的地 方转移到平均利润率高的地方, 将一个地方的利润 吸食完之后, 又转移到新的地方。这个过程不断循 环反复。空间不均衡发展既是资本积累的原因又 是资本积累的结果, 它发生在国家与国家之间、地 区和地区之间、城市和乡村之间、城市内部空间 等。每个地区的资本积累状态就像是跷跷板,一个 时期高,一个时期低。

资本积累的危机表现为资本循环出现了问 题。逐利是资本的本性, 资本积累的目的是资本循 环的过程中篗取剩余价值和实现自我不断增值(马 克思等, 2009)。当资本循环出现问题, 资本积累的 危机就来临。哈维在马克思资本循环理论的基础 上, 提出了资本累积的三次循环理论。资本的第一 次循环是将资本投到产品的生产和消费过程中; 第 二次循环是将第一次循环过程中过剩的资本转投 到城市生产性和消费性的建成环境; 第三次循环是 将资本投到科技以及医疗、教育等社会性支出领域 (Harvey, 1982)。在资本循环过程中, 由于资本家手 中的剩余价值积累太多, 工人的工资相对太少, 从 而使得最终需求领域的商品生产过剩, 进而出现了 经济危机。

“时空压缩” 是哈维(2003)在《后现代的状况》一 书中提出的现象, 同时也是一种分析理论。伴随着
交通和通讯技术的发展, 人们对时间和空间的体验 发生了革命性变化, 即先前人们所感受到的时空客 观品质不复存在。人们明显感受到时间在快速流 逝、空间在不断缩小,这便是“时空压缩”。灵活的 生产空间布局体现出后福特主义生产方式,这种生 产方式使资本带动的物质、信息和人口在空间上的 流动时间更短, 资本循环获利的周期也更短, 生产 过剩的危机周期缩短。图 1 中的现代性的福特主义 生产,与体现后现代性的后福特主义生产之间并没 有明显的界线, 后现代生产方式不过是生产层面 “时空压缩”现象(余乐, 2011)。为了实现资本更好 的积累, 资本在全球范围内不断扩张, 从而加速了 全球不均衡发展(戴维・哈维, 2003)。由于涉及到空 间维度, 因此哈维提出的时空压缩概念, 成为 20 世 纪 90 年代以来西方人文地理学的一种分析理论。

时空压缩有可能加剧乡村资本积累危机。 Marsden等(1993)在《建构乡村》一书指出，“资本主 义社会为了应对资本积累的危机, 需要创造出新的 投资机会。在这样的情况下, 一度被认为是经济活 动落后地区的农村地区反而成为许多投资首选的 地方”。时空压缩下的乡村资本积累危机表现在以 下三方面。一是在时空压缩背景下, 资本开始投在 乡村基础设施建设上。然而, 这种投资依然不能根 本解决生产过剩的问题, 只是延缓生产过剩危机的 到来。二是资本运动空间尺度扩大带来区域差异 加大。原来乡村中的资本主要投在乡村中, 但是在 时空压缩背景下, 资本可以投到乡村之外, 外来资 本也可进人乡村(如外商直接投资、乡村开发区建 设等)。乡村资本流到其他地区意味着乡村经济的 衰退; 外来资本投人到乡村, 则意味着乡村被资本 剥削。有学者认为时空压缩下的中国乡村将产生 分化和重构(黄良伟等, 2015)。三是在时空压缩背 景下,外来资本向乡村的投资可能引起乡村过度全 球市场化, 从而成为生产过剩危机的灾区。例如, 王勇等(2012)分析了苏南农村地区过度市场化后，

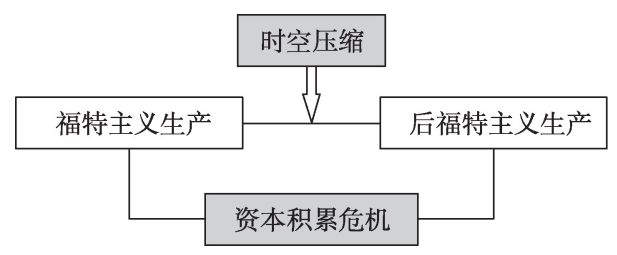

图 1 时空压缩的资本积累危机

Fig.1 The crisis of accumulation under time-space compression 
农民生产自主性降低, 并分析了伴随着空间正义缺 失和村庄共同体瓦解等风险, 乡村社会的发展最终 不可持续。哈维(2003)认为, 在没有时空压缩的情 况下,福特主义生产方式会带来资本积累的危机; 在有时空压缩情况下, 后福特主义的生产方法依然 可以带来资本积累的危机(图1)。

越来越多的地理学者呼吁从空间关联视角去 分析乡村问题。乡村地理学的领军人物 Woods (2011)采纳了Massey(2005)“联系的空间” 的概念, 提出了“联系的乡村”(relational rural)的概念, 用于 说明在全球化以及城镇化的过程中, 各国的乡村发 展与城市紧密联系在一起。在时空压缩的背景下, 乡村与全球之间, 乡村与城镇之间的物质和非物质 的要素流动更为快速(Woods, 2009)。他还提出 “全 球乡村” (global countryside) 概念 (Woods, 2007), 以 此描述乡村是如何嵌在全球资本、劳动力和商品网 络中的。这类研究案例有许多, 如美国密苏里州布 兰森 “乡村振兴”建设受外来力量影响, 表现出与原 来乡村文化不同的内容(Bascom, 2001)。目前所看 到论文多分析全球联系对乡村发展的负面影响,而 本文力图找出乡村情感、乡村社会结构等因素的影 响、中国乡村其他的投资机制。

\section{2 抵抗资本积累危机的两种方式}

(1) 在资本主义逻辑下, 抵抗资本积累危机的 形式。哈维认为, 如果资本在一定的地域范围内过 度积累, 而不能够得到充分消化的话, 资本就应该 选择新的空间来实现继续增值的目的, 这是一种更 加灵活的资本积累体制, 他用 “空间修复” (spatial fix) 的概念来描述这一地理过程。那么, 我们是否 可以将资本对乡村的投资看作是一种空间修复的 形式? 长期以来, 社会建设的艰巨性被严重地低 估。一些人以为只要经济发展了, 有了资本, 就会 有投资, 社会建设就可以轻而易举地搞好。然而这 些人不理解, 在时空压缩条件下, 社会建设会变得 更加艰巨(景天鬼, 2015)。其原因是资本流动的目 的不是发展落后地区, 而是剥削落后地区, 从而加 剧区域不均衡。此外, 按照马克思主义地理学的理 论, 外来资本进人乡村, 投资在建成环境要素(如房 地产、乡村旅游设施等), 也可能存在资本投资过 度, 资本贬值或利润率下降, 从而出现资本积累 危机。

(2) 在社会主义逻辑下, 抵抗资本积累危机的 形式。法国经济学家托马斯・皮凯蒂(2014)指出, 只
要在分配领域中实现了公平正义, 就能解决资本主 义的贫富分化问题。由此可见, 皮凯蒂期望在资本 主义生产方式框架之内寻求解决危机的出路。然 而, 哈维站在马克思《资本论》的立场上, 指出资本 自身的逻辑就蕴含着不可克服的矛盾和危机，只有 变革资本主义生产方式才可能走出危机。世界各 地的社会主义实践尚未摧毁资本主义体系。卢卡 奇、葛兰西、科尔施、阿尔都塞等西方马克思主义理 论家, 将社会主义实践的失败归结为无产阶级主观 革命意识的危机。一方面,资产阶级利用所掌握的 国家意识形态机器,宣扬资产阶级的文化价值观, 从而使工人阶级革命主体意识丧失; 另一方面, 第 二国际对历史唯物主义所作出的历史目的论和经 济决定论的庸俗解读, 忽视了人的主观精神作用。 因此,西方马克思主义将历史唯物主义从政治经济 学批判转向了注重文化和意识形态批判(张佳, 2017)。有学者分析了美国社会涌现出的制衡资本 主义的力量和形式(约翰- 肯尼斯・加尔布雷思, 2008)。本文力图结合实例, 找出这样的乡村投资 项目。

马克主主义解决资本主义危机的途径是生产 方式和生产关系的革命(理查德・沃尔夫等, 2017)。 这为探索解决乡村振兴中的资本积累危机提供了 新的视角。在没有改变生产关系的前提下,本文的 分析步骤为: 第一, 判断拥有资本的私人是否投资 在乡村非生产性的项目上, 如绿化、乡间道路等。 若如此, 则提高了乡村人们的生活福利, 相当于提 高了劳动阶层的消费能力, 从而一定程度遏制了生 产过剩。第二,判断这些人投资是否一定是追逐高 利润的地区投资的。若非此,则说明投资的目的不 是纯粹为了盈利。第三,判断这些人投资为生产性 的乡村项目时, 是否让这些项目的收益分配到乡村 劳动者手中。若此, 也一定程度地遏制了生产过剩 的危机。这个判断依据来自哈维的以下观点: 如果 一个地区的投资者并没有将剩余价值从投资地拿 走, 那么就不存在资本的区域间剥削 (Harvey, 2006)。

\section{3 时空压缩背景下的企业对广州乡村 投资的格局}

\subsection{5-2017 年企业对广州乡村投资的空间格局}

改革开放 40 年以来, 中国的乡村和城镇一样, 
经历时空压缩带来的变化。选择广州作为案例地, 是因为从这一区域单元中可较好地看到时空压缩 的现象, 即广州中心城市对周边乡村地区的影响。 在交通、通讯日益发达的当下,中国城乡之间物质、 资金、信息、人员等要素流动的状况不尽相同, 导致 中国乡村发展差异巨大(Long et al, 2010)。各级政 府通过财政转移支付手段, 投人经费建设乡村, 目 的是缩小由资本市场化流动导致的城乡差异(徐志 文等, 2015)。本文并不分析财政对乡村振兴项目 的投资, 而只是分析企业对乡村的投资, 目的是分 析哪些投资具有削减资本积累危机的积极性, 从而 为政府引导和支持提供参考。

本文的数据是在广东省发改委“广东省企业投 资项目核准备案系统” (http://www.gdtz.gov.cn/project.action)上收集到的2015-2017年企业对广州乡村 投资项目,一共 1224 项。该系统记录了每个企业投 资项目的备案项目编号、项目名称、项目所在地、项 目总投资、项目规模及内容、备案机关、审核通过日 期等信息。将项目分成为生产性项目(1101 项)和非 生产性项目(123 项)。若项目是物质商品生产或直 接为之服务的部门, 则将其定义为“生产性项目”; 若投资项目是为了满足人们环境需要和基本福利 需要的, 则将其定义为 “非生产性项目”, 如从化区 良口镇良平村的村道项目、从化区吕田镇田塘村村 民中心项目等。

图 2 是生产性项目和非生产性项目的地理分 布。用 GIS 栅格成本加权距离方法(潘竟虎等, 2012)计算项目投资点到市政府的非拥堵时段驾车 通勤时间距离, 并分为 8 个地带。由于项目数量多, 两类项目空间上交叉, 所以绘制了图 3 和图 4。它 们分别表示两种项目的投资额和项目数在 8 个通勤 时间带上的分布。图 3-4 展示的这一时期大规模的 投资项目多数都集中在近郊,企业投资在广州乡村 的主要是生产性的项目, 符合 “纯粹”市场原则, 因 为相对于远郊区,近郊区位靠近市场、交通便利、可 获得集聚效应和知识溢出效应等。上述两幅图展 示的现象与 “时空压缩”密切相关。

\section{2 企业投资乡村的两种动机}

资本投人乡村的第一动机是获得利润。若如 此, 它一定是从利润率低的城市向利润率高的乡村 转移。那么, 乡村中哪些经济领域的利润率高于城 市。以房地产业和农业为例, 有学者(周飞舟等, 2015)指出, 资本下乡有两种形式:一是企业资金参

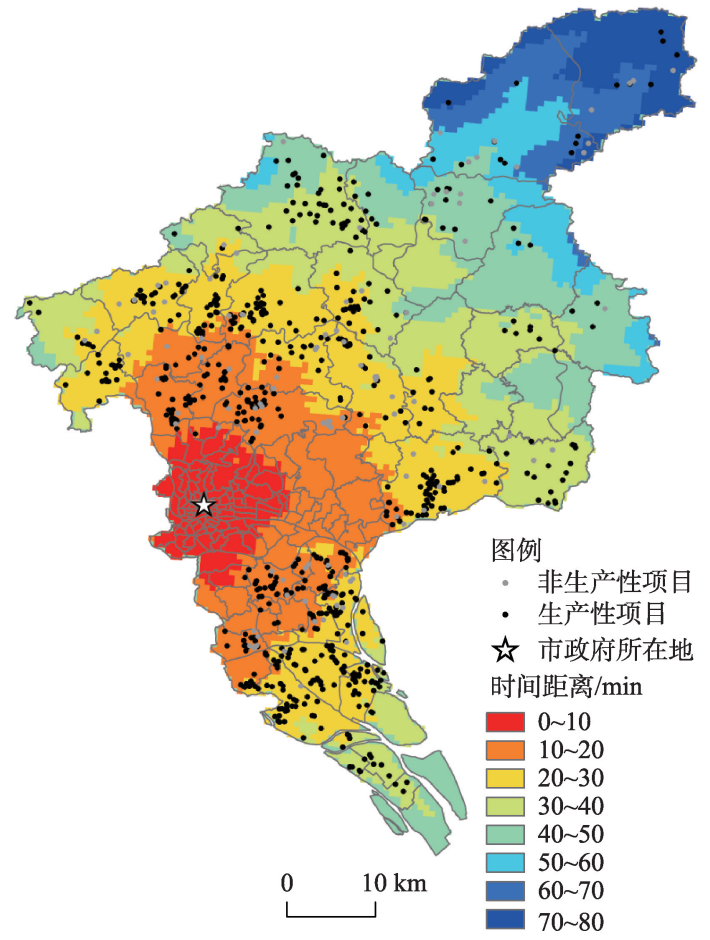

图 2 2015-2017年广州市企业乡村投资项目的空间分布

Fig.2 Geographical locations of the rural investment projects of Guangzhou City, 2015-2017

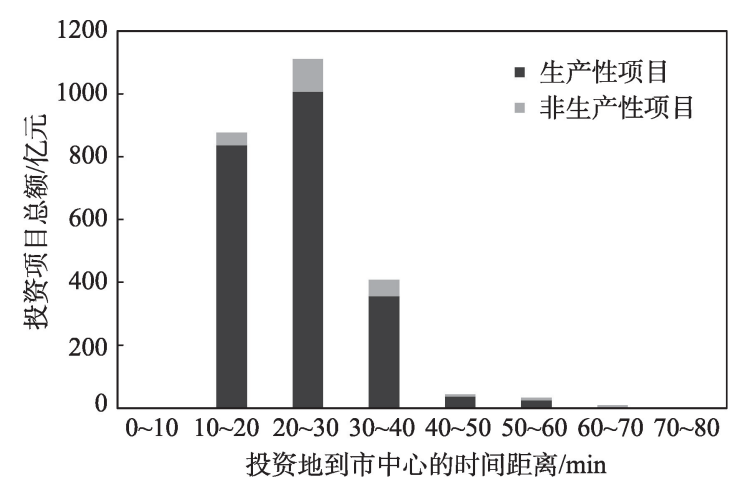

图 3 2015-2017年广州市两类企业乡村投资项目 总额的空间分布

Fig.3 Distribution of capitals of the rural investment projects of Guangzhou City by distance to the city center, 2015-2017

与了“农民上楼”为主的土地综合整治项目,作为投 资方获得了建设用地指标的剩余收益。二是形式 是企业参与了农村的耕地流转, 参与了农村土地的 规模经营,发展现代农业。还有学者(范建华, 2018) 强调, 中国乡村产业发展要遵循市场机制。但是, 只用市场机制是无法遏制资本积累危机的,例如有 研究(张弦, 2016)指出,乡村振兴的项目存在投资过 热、投资盲目带来的严重问题。资本投人乡村的第 二种动机是以获取家乡生活环境的改善和生产条 


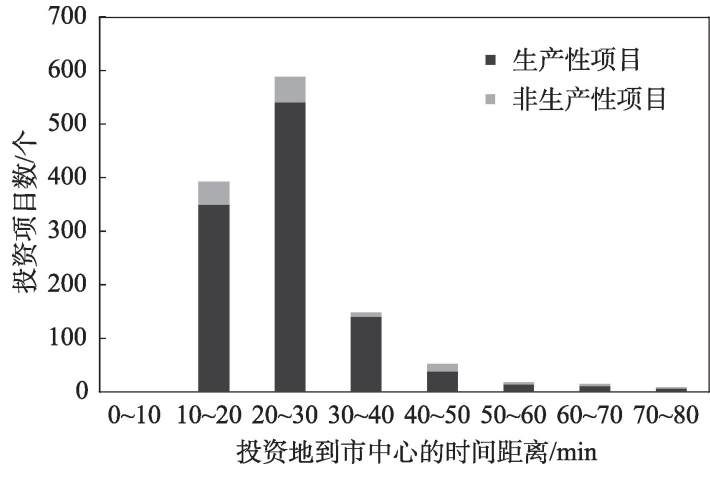

图 4 2015-2017年广州市两类企业乡村投资项目 数量的空间分布

Fig.4 Distribution of project numbers of the rural investment projects of Guangzhou City by distance to the city center, 2015-2017

件的改善,而非单纯获得利润。例如在“留住乡愁” 的乡村建设中, 有一种资本投人是为了留住村落文 化遗产(郭凯钧, 2014)。关于第二种动机, 有学者认 为这貌似一种“后现代的”、与资本市场盈利动机不 同的动机, 但是学者如果将其定义为后现代主义动 机, 则忽略了这种动机的市场背景 (Postone, 2010)。第二种动机的乡村建设投资项目一定不会 脱离市场机制的控制。因此必须依靠社会主义的 制度创新才能解决问题。

本文从项目名录中找到非盈利目的乡村投资 项目 123 项。以从化区良口镇锦村至良平村村道建 设工程(溪头段)项目为例, 该项目是由镇村共同筹 资兴建的。锦村位于从化区北部山区, 面积约 16 $\mathrm{km}^{2}$, 下辖 11 个经济社, 总人口约 900 人, 是广州市 海拔最高的行政村, 该村为良口镇重要的文化中 心。锦村至良平村村道建设工程(溪头段)项目就是 为了改善良平与锦村的社会文化联系, 而非为盈利 目的。

\section{4 结论与讨论}

\section{1 结论}

(1) 从空间分布上看, 2015-2017 年在广州乡村 的企业投资主要部分是符合 “纯粹”市场原则分布 的, 即投资项目以近郊为主, 大规模的投资项目也 集中在近郊。这种分布是 “时空压缩” 的结果。该 结论为各级政府制定解决城乡发展不平衡措施提 供了新的空间视角, 即政府应对那些靠市场机制无
法解决的乡村地区给予更多的关注和政策倾斜。

(2) 2015-2017年企业在广州乡村投资项目中 少部分并非 “纯粹”追求利润,这些投资项目多为非 生产经营性的,主要是为改变乡村生活的环境质 量, 可看作为 “空间修复”形式, 更能体现人们对幸 福生活本质的理解。这类并非纯粹为盈利的乡村 投资,其资本投资的运行逻辑为“商品 1一货币一商 品 2”(C-M-C'), 是与资本主义 “货币一物品一更多 货币”(M-C-M') 的逻辑轨迹不一致的。资本主义生 产和消费的规范植根于社会和文化交换中(Banks et al, 1997; Pemberton et al, 2010)。资本的积累依 赖一系列的文化和政治支持(Goodwin, 2006), 只有 打破社会和文化中原有的模式或结构,才能消灭资 本积累过程中的危机(Ilbery, 1998)。有学者从文化 的角度分析如何走向人性的自由,而非人性的异化 (Gleick, 1999); 还有学者从政治体制改革指出中国 走社会主义道路的必要性(Mahoney et al, 2009)。 而本文为这些马克思主义理论研究提供了案例。

\section{2 不足和讨论}

本文因为数据的局限, 在以下三个方面还有待 作进一步的深人分析。(1)未用广东全省,或全国的 乡村投资数据, 因此还看不到更大尺度空间的投资 项目分布趋势。(2)由于数据的局限, 没有分析投资 者的资金来源(自有、集资、贷款等)、利润分配形式， 因而不能细致划分哪些乡村振兴投资更能体现社 会主义价值观。(3)因为没有实地访谈资料,因此也 无法展现那些具有积极意义的乡村投资项目背后 存在的乡村情感、乡村社会结构等深层投资机制。

本文的延展思考为, 在乡村振兴的过程中挖掘 乡村的地方性,或许是克服资本积累危机的途径。 地理学挖掘乡村地方性的方法来自两种逻辑(周尚 意, 2017): 一是人地关系逻辑, 即在乡村人地关系 地域系统的概念基础上,细化了人地关系的圈层结 构。其中, 自然圈层包括了大气圈、水圈、岩石圈和 生物圈, 人的圈层包括了生计层、制度层、意识形态 层。剖析生计层、制度层、意识形态层和自然层之 间的关系, 就能挖掘乡村的地方性。二是空间关系 的逻辑, 即以全球或大尺度区域空间的关联格局为 基础,发掘地方本性(周尚意等, 2016)。只有依托地 方本性的发展, 才能一定程度上抵御资本流动带来 的区域剥削。有学者在研究乡村工业化发展过程 时发现, 由于当地没有找到地方文化之根, 只是以 
劳动力和土地相对低廉为优势发展产业, 结果当资 本找到生产成本更为便宜的地方, 就转移走了(戴 俊骋等, 2015)。

\section{参考文献(References)}

崔丽华. 2011. 大卫.哈维空间批判理论研究 [D]. 北京: 北京 师范大学. [Cui L H. 2011. Study on David Harvey's spatial critical theory[D]. Beijing: Beijing Normal University.] 戴俊骋, 周尚意. 2015. 历史层累视角下的地方形成机制探

讨: 以北京东高村镇为例 [J]. 人文地理, 30(5): 16-21.[Dai J C, Zhou S Y. 2015. On mechanism of place making in the view of 'historical layers' theory: A case of Donggaocun town in Beijing[J]. Human Geography, 30(5): 16-21.] 戴维.哈维. 2003. 后现代的状况: 对文化变迁之缘起的探究 [M]. 阎嘉, 译. 北京: 商务印书馆. [Harvey D. 2003. The condition of postmodernity: An enquiry into the conditions of cultural change[M]. Yan J, trans.. Beijing: The Commercial Press.]

范建华. 2018. 乡村振兴战略的时代意义[EB/OL]. 2018-0214 [2018-04-01]. http://m.ce.cn/jrtt/pt/201802/14/t2018021 4_28184084.shtml?tt_group_id=6522213964489687566. 2018-02-14.[Fang J H. 2018. Xiangcun zhenxing de shidai yiyi [EB/OL]. http://m.ce.cn/jrtt/pt/201802/14/t20180214 28184084. shtml?tt_group_id=6522213964489687566.

2018-02-14.]

郭凯钧. 2014. 美丽乡村建设视角下的文化遗产保护: 以萧 山乡村为例 [J]. 环球市场信息导报, (23): 57-61. [Guo K J. 2014. Meili xiangcun jianshe shijiao xia de wenhua yichan baohu: Yi Xiaoshan xiangcun weili[M]. Global Market Information Guide, (23): 57-61.]

黄良伟, 李广斌, 王勇. 2015. “时空修复”理论视角下苏南乡 村空间分异机制 [J]. 城市发展研究, 22(3): 108-112. [Huang L W, Li G B, Wang Y. 2015. The mechanism of rural spatial differentiation in southern Jiangsu based on "Time-Space Fix" Theory[J]. Urban Development Studies, 22(3): 108-112.]

景天鬼. 2015. 时空压缩与中国社会建设 [J]. 兰州大学学报: 社会科学版, 43(5): 1-9. [Jing T K. 2015. The time-space compression and social construction in China[J]. Journal of Lanzhou University: Social Sciences, 43(5): 1-9.]

理查德 - 沃尔夫, 史清竹. 2017. 资本主义危机与回归马克思 [J]. 国外理论动态, (9): 17-23. [Wollfden R D, Shi Q Z. 2017. Zibenzhuyi weiji yu huigui Makesi[J]. Foreign Theoretical Trends, (9): 17-23.]

马克思, 恩格斯. 2009. 马克思恩格斯文集(第 5 卷)[M]. 中共 中央编译局, 译. 北京: 人民出版社: 58. [Marx K, Engels
F. 2009. Makesi Engesi wenji(di wu juan) [M]. Central Compilation and Translation Bureau, Trans.. Beijing: People's Publishing House: 58.]

潘竟虎, 从忆波. 2012. 中国 4A 级及以上旅游景点(区)空间 可达性测度 [J]. 地理科学, 32(11): 1321-1327. [Pan J H, Cong Y B. 2012. Spatial accessibility of scenic spot at 4A level and above in China[J]. Scientia Geographica Sinica, 32(11): 1321-1327.]

托马斯・皮凯蒂. 2014. 21 世纪资本论 [M]. 巴曙松, 译. 北京: 中信出版社: 46. [Piketty T. 2014. Capital in the twentyfirst century[M]. Ba S S, Trans.. Beijing: China Citic Press: 46.]

王勇, 李广斌. 2012. 基于 “时空分离” 的苏南乡村空间转型 及其风险 $[\mathrm{J}$. 国际城市规划, 27(1): 53-57. [Wang Y, Li G B. 2012. Rural spatial transformation and its risk based upon "Separation of Time and Space" Theory in southern Jiangsu Province[J]. Urban Planning International, 27(1): 5357.]

徐志文, 王礼力, 谢方. 2015. 农村公共投资促进城乡经济一 体化的效率及其影响因素 [J]. 农林经济管理学报, 14(3): 252-258. [Xu Z W, Wang L L, Xie F. 2015. Efficiency of rural public investment in urban-rural economic integration and its influencing factors[J]. Journal of Agro-Forestry Economics and Management, 14(3): 252-258.]

余乐. 2011. 哈维的"时空压缩"理论及其当代文化批判[D]. 济南: 山东大学. [Yu L. 2011. David Harvey's Time-Spatial Compress Theory and the contemporary cultural critique[D]. Jinan: Shandong: Shandong University.]

约翰・肯尼斯 - 加尔布雷思. 2008. 美国资本主义: 抗衡力量 的概念 [M]. 王肖竹, 译. 北京: 华夏出版社. [Galbraith J K. 2008. American capitalism: The concept of countervailing power[M]. Wang X Z, Trans.. Beijing: Huaxia Publishing Company.]

张佳. 2017. 论大卫.哈维的资本积累危机理论及其当代价 值 [J]. 北京大学学报: 哲学社会科学版, 54(4): 24-31. [Zhang J. 2017. On David Harvey's theory of capital accumulation crisis and its contemporary value[J]. Journal of Peking University: Philosophy and Social Sciences, 54(4): 24-31.]

张弦. 2016. 乡愁经济视角下宁波休闲农业发展的理性思考 [J]. 宁波通讯, (19): 65-66. [Zhang X. 2016. Xiangchou jingji shijiao xia Ningbo xiuxian nongye fazhan de lixing sikao[J]. Ningbo Newsreport, (19): 65-66.]

周飞舟, 王绍琛. 2015. 农民上楼与资本下乡: 城镇化的社会 学研究 [J]. 中国社会科学, (1): 66-83. [Zhou F Z, Wang S C. 2015. Farmer moving upstairs and capital going down 
to the countryside: A sociological study of urbanization[J]. Social Sciences in China, (1): 66-83.]

周尚意. 2017. 四层一体: 发掘传统乡村地方性的方法 [J]. 旅 游学刊, 32(1): 6-7.[Zhou S Y. 2017. Four layers in one: The way to excavate the traditional rural locality[J]. Tourism Tribune, 32(1): 6-7.]

周尚意, 孔翔, 朱华戟等. 2016. 地方特性发掘方法: 对苏州 东山的地理调查 [M]. 北京: 科学出版社. [Zhou S Y, Kong X, Zhu H S et al. 2016. Difangxing fajue fangfa: Dui Suzhou Dongshan de dili diaocha[M]. Beijing: Science Press.]

Agnew J. 2001. The new global economy: Time-space compression, geopolitics, and global uneven development[J]. Journal of World-systems Research, 7(2): 133-154.

Banks J, Marsden T. 1997. Reregulating the UK dairy industry: The changing nature of competitive space[J]. Sociologia Ruralis, 37(3): 382-404.

Bascom J. 2001. "Energizing" rural space: The representation of countryside culture as an economic development strategy[J]. Journal of Cultural Geography, 19(1): 53-73.

Brunn S, Leinbach T. 1991. Collapsing space and time: Geographic aspects of communications and information[M]. London: Harper Collins Academic.

Gleick J. 1999. Faster: The acceleration of just about everything [M]. New York: Pantheon.

Goodwin W. 2006. Regulation rurality: Rural studies and regulation approaches[M]//Clock P, Marsden T, Mooney P H. Handbook of rural studies. Thousand Oaks, CA: Sage: 304316.

Harvey D. 1982. The limits to capital[M]. Oxford: Basil Blackwell.

Harvey D. 2006. Comment on commentaries[J]. Historical Materialism, 14(4): 157-166.

Ilbery B. 1998. The geography of rural change[M]//Phillips M. Theoretical approaches to rural restructuring: Social perspectives. London: Longman: 42.

Long H L, Liu Y S, Li X B, et al. 2010. Building new countryside in China: A geographical perspective[J]. Land Use Policy, 27(2): 457-470.

Mahoney J G, Li X L. 2009. A Marxist perspective on Chinese reforms: Interview with Jiexiong Yi[J]. Science \& Society, 73(2): 177-192.

Marsden T, Murdoch J, Lowe P, et al. 1993. Constructuring the countryside: An approach to rural development[M]. London: UCL Press: 1-2.

Massey D. 2005. For space[M]. London: Sage.

Pemberton S, Goodwin M. 2010. Rethinking the changing structures of rural local government-state power, rural politics and local political strategies?[J]. Journal of Rural Studies, 26(3): 272-283.

Poklad J. 2017. Time- space compression in Emily Brontë's Wuthering Heights[J]. Brontë Studies, 42(2): 100-108.

Postone M. 2010. Theorizing the contemporary world: Robert Brenner, Giovanni Arrighi, David Harvey[M]//Albritton R, Jessop B, Westra R. Political economy and global capitalism: The 21st century, present and future. London: Anthem Press: 7-23.

Smith M. 2011. Against ecological sovereignty: Ethics, biopolitics, and saving the natural world[M]. Minneapolis, MN: The University of Minnesota Press.

Smith N. 1990. Uneven development: Nature, capital, and the production of space[M]. London: The University of Georgia Press.

Sullivan D, Keefer L A, Stewart S A, et al. 2016. Time-space distanciation: An interdisciplinary account of how culture shapes the implicit and explicit psychology of time and space[J]. Journal for the Theory of Social Behaviour, 46 (4): 450-474.

Warf B. 2011. Teaching time-space compression[J]. Journal of Geography in Higher Education, 35(2): 143-161.

Woods M. 2007. Engaging the global countryside: Globalization, hybridity and the reconstitution of rural place[J]. Progress in Human Geography, 31(4): 485-507.

Woods M. 2009. Rural geography: Blurring boundaries and making connections[J]. Progress in Human Geography, 33 (6): 849-858.

Woods M. 2011. Rural[M]. New York: Routledge.

Yu S. 2016. Short-term monasticism in contemporary Chinese society: A case study in Bailin Temple[D]. North Carolina: Duke University. 


\title{
A geographical analysis on the positive investment projects in rural vitalization under time-space compression: \\ A case study of Guangzhou City
}

\author{
ZHOU Shangyi, XU Weilin \\ (Faculty of Geographical Science, Bejing Normal University, Beijing 100875, China)
}

\begin{abstract}
The Report of the 19th CPC Congress puts forward the strategy of rural vitalization. The role of human geographers is to participate in various rural vitalization practices and to think of it from the perspective of space and region. David Harvey, a representative of the Marxist geography, pointed out that the phenomenon of time-space compression had aggravated the crisis of capital accumulation. To eliminate the crisis needs the revolution in production modes and production relations. This study used the data of rural investment projects of enterprises in Guangzhou City from 2015 to 2017 published on the Guangdong Provincial Government' s official website, to find out what projects tried to eliminate regional development gaps and resisted the pure pursuit of capital profits. This will provide a basis for the government to target its support. The research method was empirical analysis of the statistical data. The conclusions of this study are as follows. First, the spatial distribution of investment projects indicates that the majority of the investments in the rural vitalization of Guangzhou City from 2015 to 2017 followed the "pure" market principle - the investment projects are mainly in the suburbs close to the central city, and the large-scale investment projects are also concentrated there. This distribution is the result of time-space compression. Second, a small number of the rural investment projects for rural vitalization in Guangzhou City from 2015 to 2017 are not purely pursuing profits. These investment projects are mainly on improving the environmental quality of rural areas, rather than on production. These may be regarded as spatial restoration projects, not for strengthening capital circulation. These investment projects can better reflect people's understanding of the nature of a happy life and have positive meanings.
\end{abstract}

Key words: rural vitalization; space-time compression; spatial distribution of investment; Guangzhou City 